\title{
SYMPOSIUM ON THE COLOMBIAN PEACE TALKS AND INTERNATIONAL LAW
}

\author{
GENDER PANIC AND THE FAILURE OF A PEACE AGREEMENT
}

\author{
Lina M. Céspedes-Báez*
}

Gender may have been one of the main reasons behind the rejection of the Peace Agreement in Colombia. A few hours after the narrow victory of those who opposed the deal, Senator and ex-president Álvaro Uribe Vélez gave a speech calling for the strengthening of religious family values. ${ }^{1}$ His words echoed an argument that gained traction in recent months in Colombia, particularly in the Evangelical Christian community: ${ }^{2}$ that the content of the Peace Accord dismantled traditional mores, such as the biological difference between man and woman, the importance of the heterosexual family, and the place of religion in public life.

The genderization of the Colombian armed conflict started in the early 2000s, particularly around women. International law was crucial for the women's rights movement to demonstrate to the Colombian government and civil society that women were enduring differential and disproportionate impacts of the armed conflict. Women's groups successfully deployed General Recommendation No. 19 of the Committee on the Elimination of Discrimination Against Women (CEDAW Committee) (1992), ${ }^{3}$ the Rome Statute (1998), ${ }^{4}$ and Security Council Resolution $1325(2000)^{5}$ and its progeny in order to articulate and demonstrate that women were disproportionately affected by violence.

Recently, though, lesbian, gay, bisexual, transsexual, intersex (LGBTI) issues also have become part of the gender-based reading of the conflict. Although well-known domestic NGOs, such as Colombia Diversa, have been reporting on the subject since 2004, ${ }^{6}$ for more than one decade gender in the Colombian conflict was exclusively associated with women. International law is less developed in the LGBTI area. While women's rights were equated to human rights in the 1990s, it was only in 2011 that such an equation was possible for the LGBTI population. ${ }^{7}$

The gender dimension of the Peace Agreement was rooted in international law, and mirrored its insights. The deal's rejection echoes the backlash women and LGBTI rights have been suffering around the world at the hands of conservative and religious factions. The Convention on the Elimination of Discrimination Against Women (CEDAW) is one of the human rights treaties to which the highest number of reservations

\footnotetext{
* Associate Dean and Professor of Law of Universidad del Rosario, Colombia.

Originally published online 03 November 2016.

1 Álvaro Uribe Vélez, Frente al Resultado del Plebiscito: Expresidente Álvaro Uribe Vélez.

2 Juanita Vélez \& Jineth Prieto, Santos le Quita Fe a Uribe, LA SiLla VAcía (Oct. 7, 2016).

${ }^{3}$ UN Committee on the Elimination of Discrimination Against Women, Recommendation 19, 11 th Sess. (1992)

${ }^{4}$ Rome Statute of the International Criminal Court, July 17, 1998, 2187 UNTS 38544.

$5 \underline{\text { SCOR Res. } 1325}$ (Oct. 31, 2000).

${ }^{6}$ Colombia Diversa, Derechos Humanos de Lesbianas Gays, Bisexuales y Transgeneristas en Colombia 2006-2007.

7 UN Human Rights Council Res. $17 / 19$ (July 14, 2011).
} 
has been made, while many religious leaders have framed the United Nations' and Inter-American System's efforts to protect LGBTI rights as cultural imperialism. ${ }^{8}$

In this context of conservative backlash, my contention is that the drafting of, and popular vote on, the Colombian deal became a litmus test for the legitimacy of international law developments on gender. Both the supporters and opponents of the gender-based approach saw this political process as a favorable circumstance to further their own agenda. The plebiscite's outcome demonstrates the paradoxical role international law has played in genderizing the Colombian conflict. On the one hand, it has been a powerful narrative to make certain groups stand out in the general population of victims, strengthening their demands for affirmative actions. On the other hand, it has contributed to the conservative backlash against new genderized legal subjectivities.

To make this point, this essay proceeds as follows: section I analyzes how gender was included in the peace negotiations through the establishment of the Subcommission on Gender; section II examines the genderization of the language of the Agreement; and section III considers how the renewed postplebiscite peace negotiations may alter the role of gender in a new accord.

\section{Gender Comes to the Negotiation Table}

Gender was not part, at least not explicitly, of the initial design of the negotiations. In August 2012, the Colombian government and FARC agreed to initiate peace conversations and established an agenda to discuss six points: rural reform, political participation, the end of the conflict, illegal drugs, victims, and implementation, verification, and endorsement of the Agreement. Neither women, nor gender, nor any other differential approach were included in this roadmap. ${ }^{9}$

The incorporation of gender as an integral component of the Agreement came late in the process. It took almost two years and severe pressure from social movements, particularly Colombian women's rights organizations. To respond to their demands, the parties to the negotiation agreed to create a "Subcommission on Gender", comprised of up to ten members, in which Colombian civil society and FARC would have parity in representation. The idea was to give the Subcommission the opportunity to participate actively in the negotiation process, and review what had already been settled (comprehensive rural reform, political participation, and illegal drugs).

After its establishment, the Subcommission pledged to outline recommendations for the negotiators to effectively include a gender-based approach in the Final Agreement. It identified women and the LGBTI population as the groups that would benefit from gender-sensitive measures and highlighted that taking into account such matters in a peace negotiation had no precedent in the world. ${ }^{10}$ In this sense, following recent developments in international law, the Subcommission shaped an understanding of gender that went beyond women's issues in armed conflict, embracing questions connected with sexual orientation and gender identity.

The Subcommission's work relied heavily on social movements. It held hearings with victims, women's rights, and LGBTI organizations. Its main challenge was to effectively introduce in the Agreement all the knowledge accrued in the last fourteen years on women and conflict, and turn the incipient insights on LGBTI human rights violations into operative provisions.

The Colombian women's rights movement had produced and turned into common knowledge a particular reading of women in conflict. This enabled them to successfully genderize an internal armed conflict that was

8 Omar G. Encarnación, The Troubled Rise of Gay Rights Diplomacy, 115 CurRent Hist. 17, 19 (2016).

${ }^{9}$ Gobierno de la República de Colombia \& Fuerzas Armadas Revolucionarias de Colombia, Acuerdo General para la Terminación del Conflicto y la Construcción de una Paz Estable y Duradera (Aug. 26, 2012).

${ }_{10}$ Mesa de Conversaciones, Comunicado Conjunto 345-356, (Sept. 11, 2014). 
mainly read for several years from the neutral vantage point of forced displacement. To do so, they advanced a gender-based reading of forced displacement using claims of sexual violence and CEDAW Committee General Recommendation No. 19. This authoritative interpretation of CEDAW affirmed that gender-based violence is discrimination; that is, it is violence that either targets women specifically, or impacts them disproportionately. This move allowed women's rights movements to establish a connection between the paradigparadigmatic gender-based crime of sexual violence against women and forced displacement in Colombia. Women's rights NGOs thus made the case that the conflict was imposing disproportionate and differentiated impacts on Colombian women, as compared to men.

Sexual violence was interpreted as mainly heterosexual, men against women, and was tightly linked to forced displacement as its cause and/or its consequence. What differentiated internally displaced women and men was the incidence and role of sexual violence in this setting. Thus, sexual violence became the marker of womanhood in the context of the Colombian armed conflict, the epitome of the gender-based crime, and the device that made men's and women's experiences incomparable. This argument was pervasive. The Constitutional Court embraced and turned it into common legal knowledge in Writ 092 of $2008 .{ }^{11}$ It also became the foundation to explain other harms women were enduring in conflict, such as land seizure and forced abandonment, as well as other crimes associated with their political participation or human rights activism. ${ }^{12}$

In contrast, LGBTI organizations have faced greater challenges in building a tailored knowledge to provide a particular interpretation of the gross rights violations they have suffered in this conflict. Their advocacy has been mostly centered on extending heterosexual couples' rights to same-sex couples through strategic litigation. Therefore, their discourse and claims related to the armed conflict still depend mostly on the women's rights movement's achievements. For instance, the most representative entry point for armed conflict-related LGBTI issues in Colombian law was encrypted in a 2015 Constitutional Court writ on women in the conflict. ${ }^{13}$ In it the Constitutional Court mentioned that women with diverse sexual orientation are highly exposed to sexual violence. Moreover, lack of a more precise and robust international LGBTI rights law seems to hinder any further development in a country that has relied so much on international norms to understand its own conflict.

\section{The Genderization of the Peace Agreement}

The Subcommission was careful to incorporate inclusive language throughout the document and to mandate gender mainstreaming for every action, plan, and program that was agreed upon. Mentioning "men and women" was a tactic to guarantee both sexes were going to be part of new and renovated institutions responsible for the implementation of the Agreement, beneficiaries of public policies, and taken into account in the design of actions and plans. The word "women" was used to link the Agreement to the common knowledge built in international and domestic law around their experiences in conflict. The expressions "sexual orientation," "gender identity" and "LGBTI" were deployed to identify one vulnerable group, among others, that has been subjected to violence and discrimination. "Gender" was a multipurpose term sometimes used to summarize all the inclusive language anchored in sex and sexuality, or to underscore one of its expressions. In general, it was employed as a synonym for women and was a device to call for differentiated measures to enforce their rights and recognize their experiences in conflict.

\footnotetext{
${ }^{11}$ Corte Constitucional [C.C.] [Constitutional Court], abril 14, 2008, Auto 092 (Colom.)

12 See C.C., mayo 21, 2013, Auto 098.

13 C.C., enero 27, 2015, $\underline{\text { Auto } 009}$.
} 
The Agreement does not provide a new take on gender and conflict different from the one that was already present in international and domestic arenas just before the negotiations began. Women's issues were at the center and LGBTI's followed in their path. Even though the invocation of gender in several sections explicitly or implicitly included LGBTI persons, most of the time, its operationalization ended up in provisions entrenched in the traditional binaries of men and women, disregarding sexual orientation and gender identity. This could have been the case either because LGBTI was not a pertinent category to explain certain harms or design particular policies, or there was not enough accrued expertise in the social movement to propose and advocate for specific measures.

Point 1 of the Agreement, which deals with comprehensive rural reform, illustrates this scenario. In its opening paragraphs, gender is utilized as a general category, then to talk about men and women, and then, further in, it is turned into an overarching device to encompass all vulnerable groups given their sex and/or sexuality. However, immediately after the room for aspirational language is exhausted, gender becomes a binary and is translated mostly into concrete measures to benefit women. The principle of "Equality and Gender Perspective," one of the standards set up to guide the implementation of what was agreed in this point, speaks exclusively about women and was drafted to achieve one precise goal: to challenge the traditional portrayal of rural women tied to reproduction, victimhood, and the economics of care.

The scarce mentions of sexual orientation and gender identity in Point 1 are aimed solely at providing a complete characterization of the rural population, in tandem with ethnicity and age group. The lack of strong diagnoses and knowledge linking LGBTI issues to land tenure problems made it difficult to turn these concepts into more than descriptive tools. Also, neither domestic nor international law provided an avenue to mention them. By contrast, there is robust national and international evidence connecting the fact of being a woman to hurdles in accessing, controlling, and recovering real property rights. ${ }^{14}$ These bodies of law have addressed this situation through public policy and/or legislation, respectively. ${ }^{15}$ The Agreement, then, merely reflected the state of the art in this discussion, staying well inside its boundaries.

Point 2, on political participation, employed a similar strategy as Point 1. Closely following United Nations Security Council Resolution 1325 and General Recommendations No. 23 and 25 of the CEDAW Committee, the Agreement placed its accent on women and recognized the importance of their political participation to build strong democratic societies. ${ }^{16}$ However, there was a significant difference from Point 1: an explicit government commitment to promote, among others, the LGBTI social movement and fight LGBTI stigmatization. This move was not only supported in international law, but was in line with Colombian constitutional case-law that had identified a legal protection deficit for the LGBTI population in the Colombian legal system. ${ }^{17}$

The rest of the Agreement replicated the gender-based approach laid out in Point 1. For that reason, women ended up as the epitome of gender, while sexual orientation and gender identity were set aside as residual concepts employed, in parallel with other categories relating to vulnerable groups, to introduce nuances to the diagnoses or make visible the crimes that particularly impacted these communities. If the peace deal demonstrates something, it is the pervasiveness of the equation between gender, women, sexual violence, and armed

${ }^{14}$ Land Tenure, Property Rights, and Gender, USAID (Aug. 16, 2013); Naomi Kenney \& Ana Paula de la o Campos, Developing GenderEquitable Legal Frameworks for Land Tenure, FAO LEGAL PAPERS No. 98 (2016).

${ }^{15}$ Convention on the Elimination of All Forms of Discrimination Against Women arts. 14 to 16, Dec. 18, 1979, 1249 UNTS 85; L. 731/02, enero 16, 2002, DIARIO OFICIAL [D.O.] 44.678 (Colom.).

16 UN Committee on the Elimination of Discrimination Against Women, Recommendation 23, 16 th Sess. (1997) and UN Committee on the Elimination of Discrimination Against Women, Recommendation 25, 30 $0^{\text {th }}$ Sess. (2004)

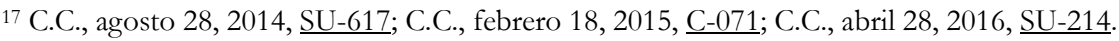


conflict, and the embryonic and contested state of LGBTI knowledge to contribute to transitional justice design.

\section{Gender Panic Fueling an Uncertain Future}

At the time of writing, it is unclear what the future holds for the Peace Agreement. Its rejection, based partly on the perception that its text upset traditional values, points to a wider gender panic Colombia is experiencing due to the recent victories of the LGBTI movement, and the emerging support that a sector of the international community lends to LGBTI groups and issues. Since there is a strong equation between gender and women, and some of the women's rights movement's strategies have been replicated and translated to advocate for LGBTI rights, any backlash against the LGBTI population resonates in women's ranks. The contestation of gender as a useful category to understand the differentiated impacts of social events jeopardizes the entire genderization of the armed conflict in Colombia.

International law and its appropriation of gender played a pivotal role in making women stand out as a group with different needs and experiencing different harms in Colombia. However, this legal corpus has not been able to replicate this contribution with the same decisiveness for the LGBTI population.

If renegotiation is the next step, gender would be likely toned down to appease the Colombian society's gender panic. It is probable that the women's rights movement's historical claims in relation to land tenure and political participation will remain, mirroring where international law has produced more insights, and that the few references to sexual orientation and gender identity will disappear. Indeed, the document FARC produced to summarize and present the Peace Agreement to its members prefigures this outcome. "Gender" was fused into "women," and LGBTI was an acronym included only once to refer to this social movement's support for the negotiation. ${ }^{18}$

The Colombian peace process has left different lessons for diverse social and political actors. In this particular case, it has reminded the women's rights and LGBTI movements that their victories are far from consolidated, and that having international law on one's side can be a start but not a guarantee against setbacks and regressions. The plebiscite outcome does not only mean the revision of the Agreement, but also the reconsideration of the place of gender in the understanding of conflict.

${ }^{18}$ Fuerzas Armadas Revolucionarias de Colombia, Tesis para la Discusión. 